\title{
Assessment of Former Manors as Rural Landscape Elements: Case Study of Northern Lithuania
}

\author{
Ingrida SAULIENE*, Laura SUKIENE, Erika ZALESKIENE, \\ Audrius SAULYS, Kestutis AUKSELIS \\ Siauliai University, 38 Visinskio, LT76352, Siauliai, Lithuania; ingrida.sauliene@su.lt ("correspondingauthor); laura.sukiene@su.lt; \\ erika.zaleskiene@gmail.com;saulysaudrius@gmail.com; saulessilas@gmail.com
}

\begin{abstract}
Evaluation of the former manors as rural landscape elements and identification the recreational potential of former manor environments is discussed in this study. Paper analyses the infrastructure and landscape components of former manors located outside settlements in the district of Pakruojis, Lithuania, and examines their suitability for employment within recreational activities. Historical data on former manors were collected by analyzing archival material and were supplemented with information obtained during expeditions by interviewing the people who currently live in the former manors. All described manors, buildings, and historical greenery have been established in open places. No parts of villages, roads, forest or forest stands are incorporated in these territories. The surveyed former manors are accompanied by parkland. The manor parks analyzed in this study are dominated by native plants, which account for at least $75 \%$ of the trees. An analysis of the diversity of the species revealed that Tilia cordata prevails (54-74\%) in the majority of manors. The variety of park styles reflects the evolution of the European parks from Baroque parks (Geruciai, Pamusis II) to Romanticism (Dovydiskis) style. Visitors can marvel at the greenery composition of historic parks, explore age-old (Pamusis II, Geruciai) and fabled (Pavezgiai, Pamusis II) trees, and taste the fruit from historical orchards. In the studied territory there is a need to preserve the manor parks because they make a specific contribution to the overall form and aesthetic of the rural landscape, play an important role in the conservation of biodiversity, and represent significant cultural and historical landmarks.
\end{abstract}

Keywords: cultural heritage; globalization; historic greenery; historical parks; land use diversification; nature recreation

\section{Introduction}

Globalization has spread throughout the world and is now directly impacting small states (Bebbington and Batterbury, 2001; Cheshire and Woods, 2013). Following the collapse of the Soviet Union, the Baltic States regained their statehood and, subsequently, engaged in intensive processes of globalization (Šliburyte and Masteikiené, 2010). Doing so undoubtedly added value to the country's development through delivering benefits such as expanding business opportunities and the size of the potential market, increasing tourism, providing citizens with an opportunity to become acquainted with other cultures, and allowing the integration of modern international regulations into Lithuanian legislation. Along with these progressive processes, negative implications, such as migration, degradation of ethnic culture, and biodiversity loss (Lazdinis et al., 2005; Elsner, 2010; Kamičaitytè-Virbašienè and Gražulevičiūtè-Vilenišké, 2010; Janulyte et al., 2011;
Vaiškūnaitè et al., 2012), have also been observed in Lithuania (Paulikas and Lazdinis, 2006). Due to emigration, an intense rural depopulation, leading to the extension of farms, agroecosystemic desertification, and prevailing monoculture landscape has emanated. The evolvement of the landscape in Europe is significantly associated with the spread of urbanization into rural areas, while the current landscape of Lithuania is essentially determined by anthropogenic processes related to agricultural development (Pašakarnis and Maliene, 2010). A relatively small area of the country, historically formed via agricultural traditions and related businesses, preconditioned the formation of the rural landscape.

The evolvement of the agrolandscape has proceeded in two directions: In areas that are difficult to access (wetlands or hilly areas) active succession, leading to the formation of low-value stands, has taken place, while fertile plains have been occupied by strong and large farms that have intensively exploited territorial resources and reduced biodiversity and recreational potential. In fact, about $70 \%$ of 
the country's population currently resides in cities (Statistics Lithuania, 2018), and the leisure activities that such urban dwellers are particularly attracted to are typically located outdoors in areas of natural beauty. However, access to these resources has been limited to a certain extent due to the degradation of the natural landscape. A potential solution to this dilemma could involve using former manors and their accompanying parks.

Naturally, manors should be considered the historicalcultural basis of the current landscape scene (Gražulis, 2008) because farms and villages have been established around them under changing political-economic conditions. Towns have formed around most of the big manors towns, yet others have remained as distinct farms. Consolidation of such farms was particularly intense during the Soviet period as a means of promoting land drainage (Vaitkus and Vaitkuviene, 2005). In 1990, after the restoration of independence, conditions for the further transformation of rural landscapes were established. People actively began to develop small agrarian farms (Mincyte, 2011), and this activity was particularly evident in the former manors situated outside village areas. In the overall course of political-social decisions, the local population did not deviate from heritage and traditions; as such, the issues related to the utilization and/or conservation of manors remain extremely relevant today. As they can be found dotted throughout the landscape, the former manors play both an important visual and spatial role in the area. However, the actualization of their role in the development of the rural landscape has not yet been sufficiently analyzed in depth. In the present day, manor complexes, which consist of a mansion house, residential and farm buildings, and parks, are active landscape elements that are included in the landscape policy.

The concept of historical greenery and heritage conservation in Lithuania is based on provisions adopted by Florence and Venice Charters. The generic term for historical greenery that is typically employed in international literature is garden while, in Lithuania, historical greenery is traditionally referred to as park (Kačinskaité, 2009). Preservation and renovation of such objects as intended for the reconstruction of authentic vegetation and other items are carried out in accordance with the integrated architectural compositions of cultural ensembles. Renovation of greenery is only permitted if it does not modify the original design ideas and the composition of vegetation, open spaces, and proportions of greenery.

The purpose of this research is to evaluate the former manors as rural landscape elements and to identify the recreational potential of former manor environments. This paper analyses the infrastructure and landscape components of former manors located outside settlements in the district of Pakruojis and examines their suitability for employment within recreational activities.

\section{Materials and Methods}

\section{Study area}

Lithuania is a small $\left(65302 \mathrm{~km}^{2}\right)$ Central European country that is located on the Baltic Sea and has a prevailing marine continental climate. As a result of its favorable climatic conditions, temperate deciduous forests dominate the country. Coniferous stands occupy the largest land mass, covering an area of $56.3 \%$, while deciduous forests account for $43.8 \%$ of all forest area (Ministry of Environment and State Forest Survey Service, 2012). Forests cover one-third of the total landmass of Lithuania and, as such, are an important part of the natural landscape. In addition to being protected areas, the forests are also home to the majority of the country's recreational facilities. Lithuanian territory is unevenly covered with forests, and this serves to reduce the attractiveness of certain areas. According to Statistics Lithuania (2018), an increase in demand for shortterm out-of-town tourism has increased in Lithuania by over $61 \%$ over the last five years. Former manor parks may represent a viable option by which it is possible to meet the population's needs for natural recreation activities in sparsely wooded areas. Today, the processes of environmental management are still very much influenced by the surviving heritage of the manors. At present, the register of cultural values lists 582 manors, of which only $20 \%$ are state and municipal property. Of the remaining manors, $38 \%$ are private, and $42 \%$ are of mixed ownership (Gražulis, 2008). Approximately 800 green spaces (parks or their fragments) accompany the manors. However, the majority of the surviving historical greenery is located in poorly urbanized areas; i.e., in rural landscape, which occupies about $75 \%$ of the country's territory (Bukantis et al., 2008).

Forest cover here is one of the lowest in the country (only 19.6\%); as such, manor complexes play an important role in shaping the sustainability of the landscape. For the purposes of this study, the former small manors (Fig. 1) of

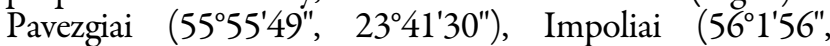
$\left.23^{\circ} 57^{\prime} 3^{\prime \prime}\right)$, Pamusis II $\left(56^{\circ} 2^{\prime} 37^{\prime \prime}, 23^{\circ} 59^{\prime} 14^{\prime \prime}\right)$, Dovydiskis (56 $\left.55^{\prime} 51^{\prime \prime}, 24^{\circ} 0^{\prime} 51^{\prime \prime}\right)$, Aukstadvaris ( $\left.56^{\circ} 6^{\prime} 44^{\prime \prime}, 24^{\circ} 6^{\prime} 20^{\prime \prime}\right)$, and Geruciai $\left(56^{\circ} 19^{\prime} 28^{\prime \prime}, 23^{\circ} 59^{\prime} 20^{\prime \prime}\right)$ were selected because their geographical position makes them convenient for people seeking recreational opportunities. The former manors are located on the historically significant trade route linking Lithuania and Latvia.

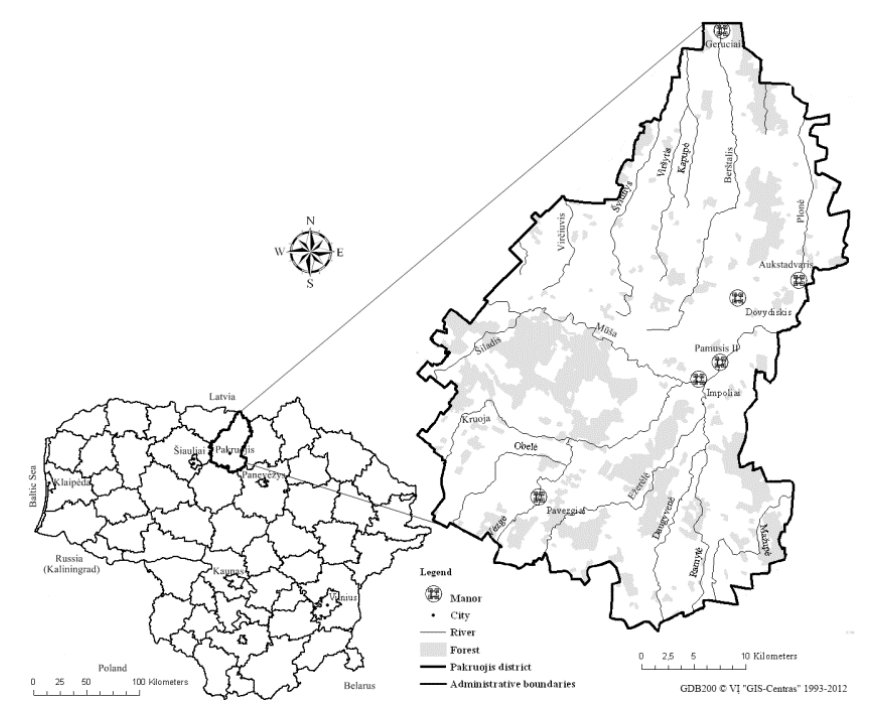

Fig. 1. Map of former manors in Pakruojis district 
Table 1. Time of establishment and size of the former manors

\begin{tabular}{ccc}
\hline Former manor & Established & Size $(\text { ha })^{*}$ \\
\hline Pavezgiai & $1^{\text {st }}$ half of the $19^{\text {th }}$ century & 8.9 \\
\hline Impoliai & $1^{\text {st }}$ half of the $19^{\text {th }}$ century & 33.2 \\
Pamusis II & $1^{\text {st }}$ half of the $16^{\text {th }}$ century & 45.4 \\
Dovydiskis & $2^{\text {nd }}$ half of the $18^{\text {th }}$ century & 17.9 \\
Aukstadvaris & $1^{\text {st }}$ half of the $19^{\text {th }}$ century & 15.6 \\
\hline Geruciai & $2^{\text {nd }}$ half of the $16^{\text {th }}$ century & 18.9 \\
\hline
\end{tabular}

All the manors listed above are located in an agriculture area that is particularly fertile. Due to intensive agricultural practices in this region, forests have not formed. Agricultural areas increase with changing land use traditions (Statistics Lithuania, 2018). Forested areas are relatively small, and the landscape is fragmented, and that poses a threat to biodiversity and the sustainable development of the area. The former manors chosen for the study differ in terms of the time at which they were established and the size of the territory that accompanies them (Table 1).

Currently, the first five former manors are privately owned. In Geruciai, the situation is relatively complicated because the larger part of the manor is owned by one owner, and the farm-hand and servant buildings have been converted into apartments (each apartment belongs to a separate owner). All former manor houses are included in the register of cultural values; however, because of investment shortage, they are not revitalized. To ensure the sustainable development of the landscape and coherence of socio-economic relations, these heritage sites require further evaluation in terms of their future potential.

\section{Data collection}

\section{Database analysis and mapping}

Historical data on former manors were collected by analyzing archival material (Table 1), geodesic plans, maps, and the Lithuanian manor database and by interviewing specialists from the Pakruojis Cultural Department. Only the homesteads in which the buildings form a complex with historical greenery and are harmoniously integrated into the rural landscape were selected for the study. The accumulated data were supplemented with information obtained during expeditions by interviewing the people who currently live in the former manors.

A location map of the studied items was prepared using ArcInfo10 GIS (Esri Global, Inc.) software and the Lithuanian geoinformation database $\mathrm{GDB}^{\circ} 00^{\circ}$ (GISCentras) compiled on the basis of M1:200000 topographic maps. Aerophotographs and ArcInfo10 GIS software were used to determine the spatial and structural coverage of the area. The changing dynamics of the natural and anthropogenic structural elements and components were estimated using ORT10LT 1995 (monochrome raster) and ORT10LT 2009 (color raster). The year 1995 was chosen as the starting year in order to reflect the situation of the former manors immediately after the restoration of independence. The relative sizes of the buildings, roads, water bodies, agricultural land, and green spaces were calculated using AutoCAD 2011 (Autodesk Inc.) software.

\section{Field studies}

Field studies were conducted via a series of expeditions. During these visits, the buildings, small architecture objects, and structured spatial layout of each former manor were reviewed and analyzed, and particular attention was focused on the state of the manor parks.

The condition of the buildings and small architecture objects were analyzed to identify their current function and state and to estimate their suitability for employment as recreation venues in the future. The areas of greenery that accompanied the former manors were evaluated according to species composition and abundance of woody plants, tree age and condition, and the overall state of the park and recreational resources. The species composition of native and/or introduced trees that were growing in the parks was determined. Tree age was estimated according to to Majdecki (1980-1986). The condition of the parks was evaluated following Januškevičius et al. (2006).

Recreational resources were assessed in terms of the accessibility of the territory and the overall characteristics of the landscape; e.g., distribution of water bodies and their quality, spatial diversity of vegetation (grasslands/tree stands), entirety of anthropogenic objects, and naturalness/artificiality ratio.

\section{Statistical analysis of the data}

The data pertaining to the architectural objects are presented in graphs. This facilitates the extent to which these objectives are leveraged in the overall context and with respect to other objects. The collected data were systematically assessed, and results are presented using the basic numerical characteristics of data dispersion. Landscape elements were divided into two generic groups: 1) The former manor buildings and small architecture objects, 2) green spaces and natural objects. To compare data samples across multiple sequences, graphical visualization was performed as a means of revealing the relationship between separate elements within the entirety of the landscape elements in the former manors. This made it possible to compare the share of each object with regards to the sum of the assessed landscape elements in a particular manor. Analysis of the data of historic woody greenery is provided as the percentage of native and introduced tree species and diversity in the context of each of the former manor park and all parks together. Box-Whisker plots, combining data range, quartile range, variance, and standard deviation, were employed to depict the age of the trees found on the parks. 


\section{Results}

\section{Infrastructure of former manors}

In the Geruciai and Pavezgiai manors (Fig. 2), the majority of the original buildings have survived. However, various residential buildings (mansion, officinas, farm-hand building, gardener's house) have been modified, and some have been abandoned or neglected and are now standing derelict. During the Soviet occupation, the Pamusis II manor buildings were almost destroyed and only one small farm building survives. After the restoration of independence, the old buildings were returned to their former owners; however, their privatization did not have a positive impact on the state of the buildings. The studies performed as part of this research revealed that, if no substantive measures are applied, the surviving buildings will completely decay.

Representational buildings, such as stables and coach sheds, were situated closest to the mansion. Nowadays, these buildings are used for other purposes, mainly for agricultural machinery and production storage. The buildings that are used for household purposes, such as barns, sheds, and cellars, have survived in the majority of manors. However, the buildings intended for manufacturing purposes have only endured in the Geruciai manor. The small architecture objects that have survived in the former manors represent unique architectural and historical items. In the center of Pavezgiai manor park, the folk-style sculpture of a White Angel (Fig. 3a) is positioned at the entrance to the estate, and a graceful red-brick sacral chapel of Holy Mary (Fig. 3b) surrounded by lime trees can be found. A Romantic-style chapel is located on a hill in the Dovydiskis manor park. The living elements of the landscape enhance the aesthetic value of the anthropogenic environment. Half of the surveyed former manors are in the plains; the other half are located in hilly terrain. Following the European garden design examples, the developers of the latter manors formed the Italian terraces on the hills. Such elements of landscape architecture are clearly visible only in the Dovydiskiai manor (Fig. 4).

The attractiveness of the analyzed manors is emphasized by the natural and artificial water bodies situated on their terrain (Fig. 4). Four of the manors, Pavezgiai, Impoliai, Pamusis II, and Geruciai, are situated near rivers. Dovydiskis is distinguished by complex engineering structures. Here, an artificial water reservoir has been constructed that retains water from the springs. Due to the design of the system, the water from the artificial reservoir flows in the direction of the slope between the park terraces.

All described manors, buildings, and historical greenery have been established in open places. No parts of villages, roads, forest or forest stands are incorporated in these territories. The surveyed former manors are accompanied by parkland. Pavezgiai, Dovydiskis, Aukstadvaris, and Geruciai manors have old orchards that contain trees that are 80-100 years old. Systems of Baroque-style alleys, which consist of circumferential rows of trees of various purposes, give solemnity to the former manor homesteads. These compositional elements could be clearly identified in five estates. In Geruciai, only short stretches have survived. The representational alley leading towards the mansion is best preserved in Dovydiskis, while in Pavezgiai and Impoliai estates only fragments of such alleys remain. In these parks, alleys are formed in regular geometric patterns. In some places, the trees have lost their ornamental features, but the alleys are still aesthetically valuable.

Currently, the infrastructure remaining in the former manor areas is not only historically important, but also could form the ideal basis for the development of new types of business and services.

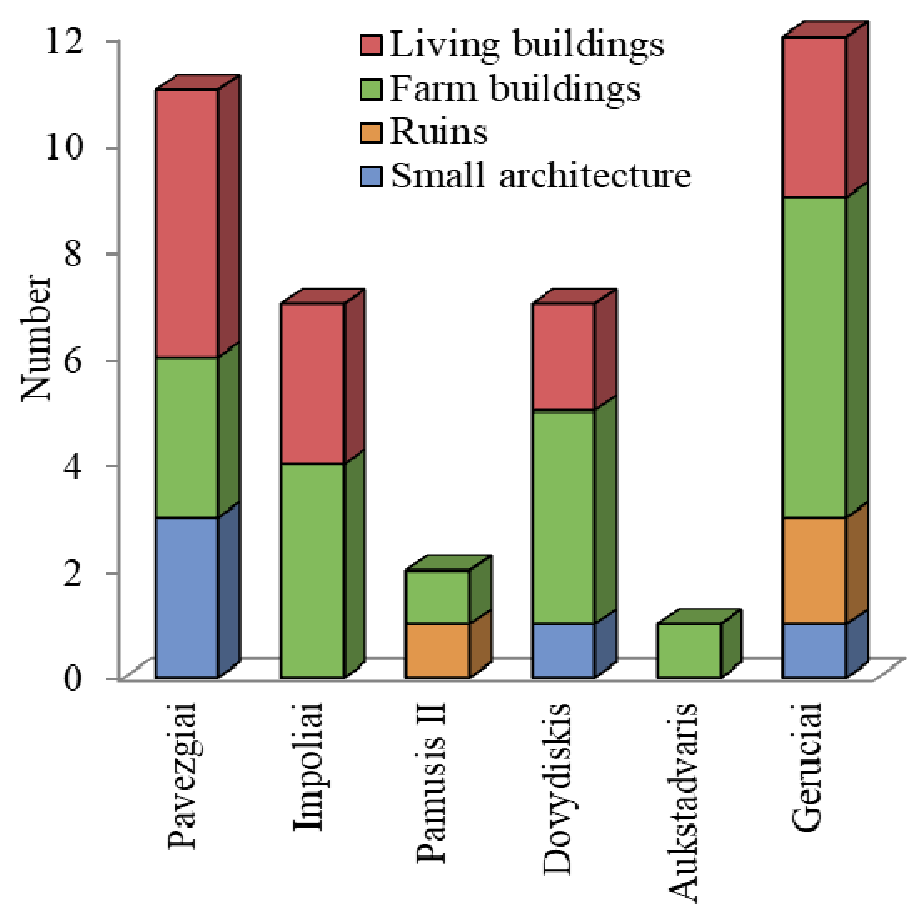

Fig. 2. Former manor structures 

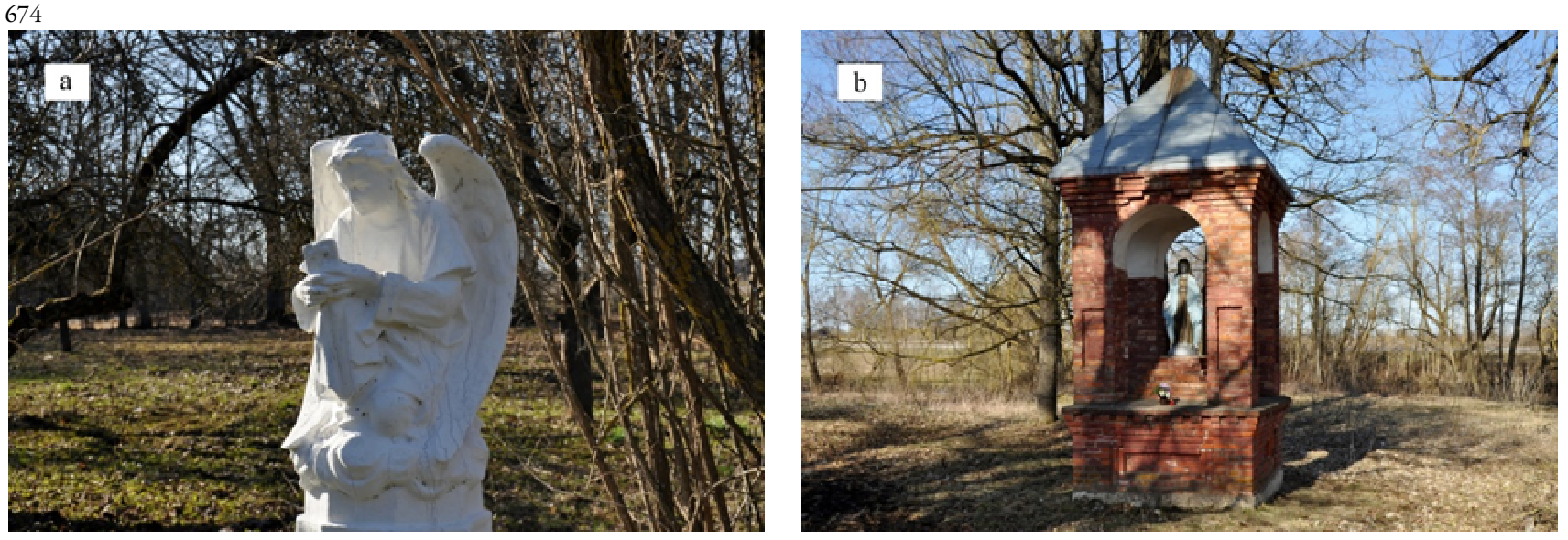

Fig. 3. Sculpture of White Angel (a) and chapel of Holy Mary (b) in park of the former Pavezgiai manor

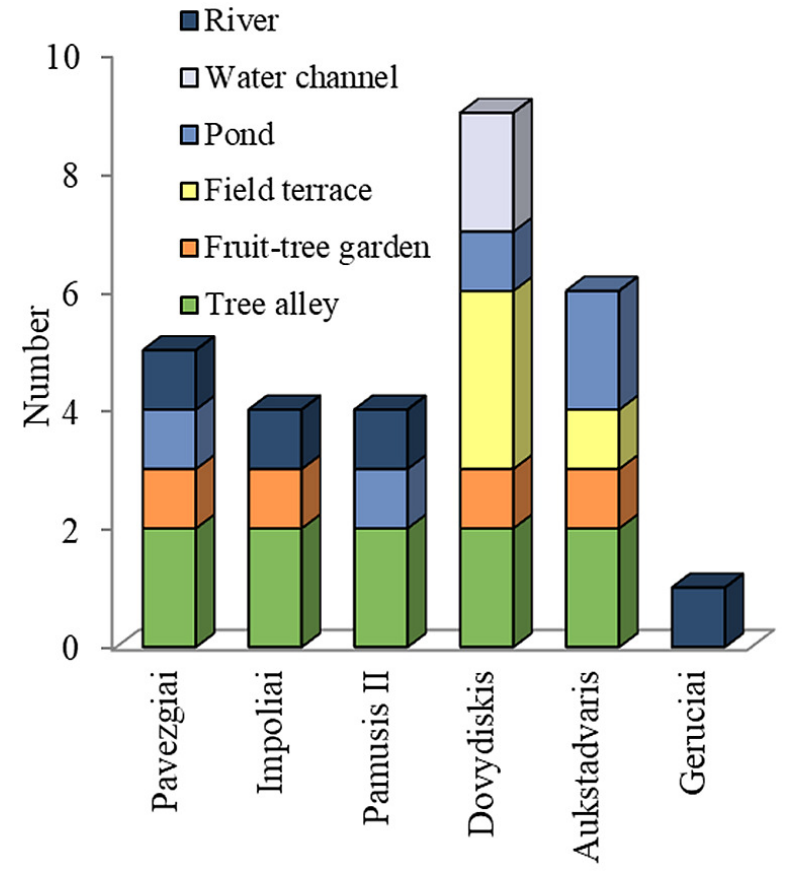

Fig. 4. Natural objects in the former manors

Greenery of former manor parks

The manor parks analyzed in this study are dominated by native plants, which account for at least $75 \%$ of the trees (Fig. 5a). This is typical of Lithuanian manor parks. Historic parks are characterized by rather poor plant assortment. Homesteads were most often planted with traditional native tree species. An analysis of the diversity of the species revealed that Tilia cordata prevails (54-74\%) in the majority of manors (Fig. 5b). Acer platanoides is grown in all parks and comprises 10-36\% of the investigated stands. Quercus robur and Fraxinus excelsior are commonly found in manor parks in Lithuania; therefore, their presence in manor parks located in the Pakruojis district is to be expected. A comparison of the parks revealed that Fraxinus excelsior (more than $18 \%$ of the total tree count) was most abundant in Dovydiskis park. Furthermore, Quercus robur was one of the predominant species in Geruciai (more than 30\% of the total tree count). Trees of other species (Picea abies, Pinus sylvestris, Salix fragilis, Betula pendula, Ulmus glabra) comprised less than $8 \%$ of the population. Aesculus hippocastanum L., Populus canescens (Aiton) Sm., Larix sibirica Ledeb. were most frequent among the introduced (Fig. 5a) species.

Parks of the former manors ascribed to the second group are similar in terms of both the diversity and abundance of the tree species. Tree age (Fig. 6) is certainly an important benchmark for the historical value of the park. The trees found growing in the parks of the manors assessed in this study were younger in comparison to the isolated greenery items of the homesteads. Quercus robur were the oldest surviving trees, and some of the specimens found were as old as 170 years. The average age of the dominating Tilia cordata was about 120 years. The Tilia cordata trees growing in Geruciai can reach as old 160 years. The oldest Tilia cordata of Lithuania was planted in the first half of the 18th century (Isokas, 1995). Aesculus hippocastanum are the oldest surviving introduced plants. In the investigated parks, they were between 120 and 150 years old. 

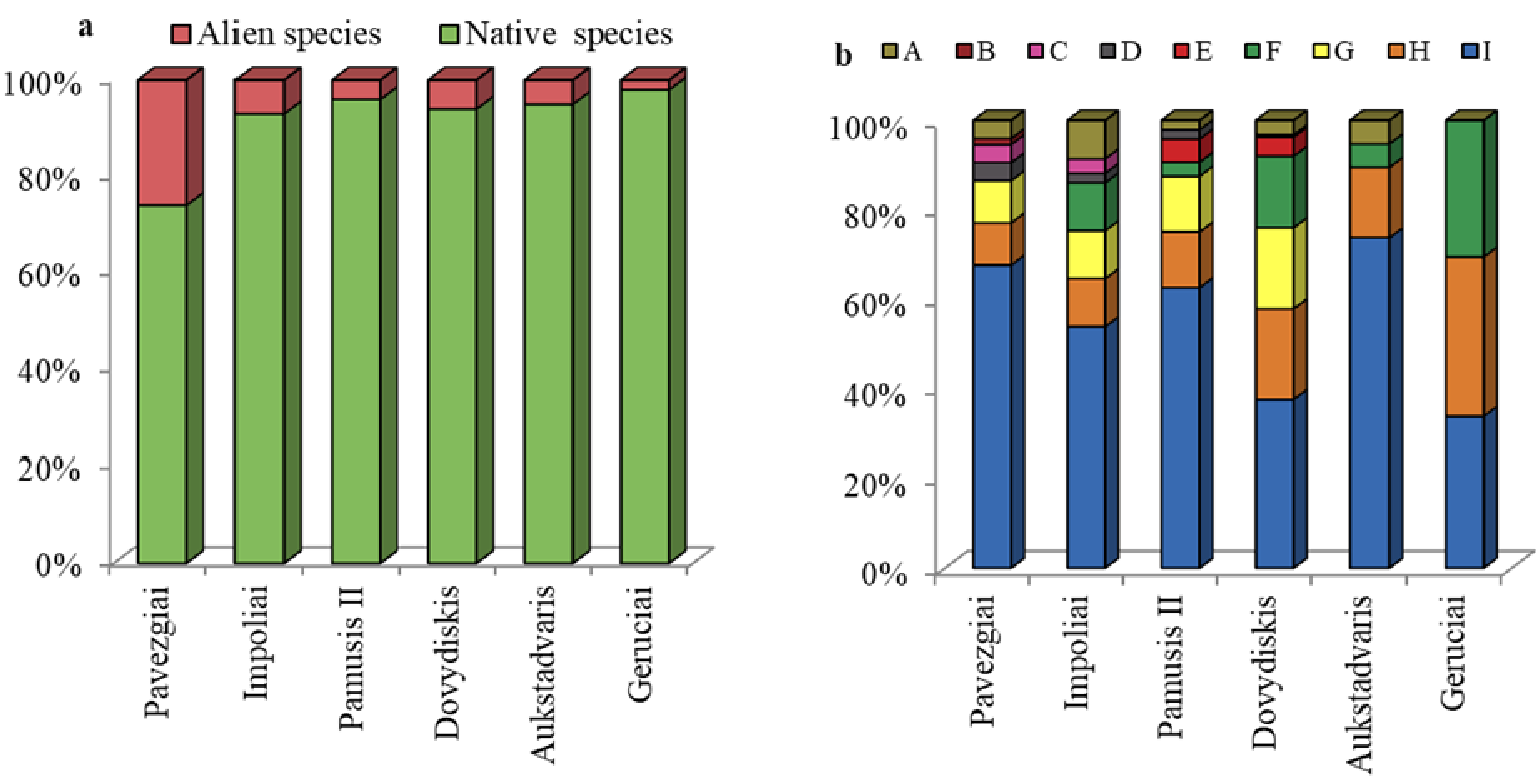

Fig. 5. Trees in the parks of former manor: $\mathrm{a}$ - ratios of native and introduced tree, $\mathrm{b}$ - variety of native tree species. A - Picea abies L., B - Pinus sylvestris L., C - Salix fragilis L., D - Betula pendula Roth., E - Ulmus glabra Huds., F - Quercus robur L., G Fraxinus excelsior L., H - Acer platanoides L., I - Tilia cordata Mill.

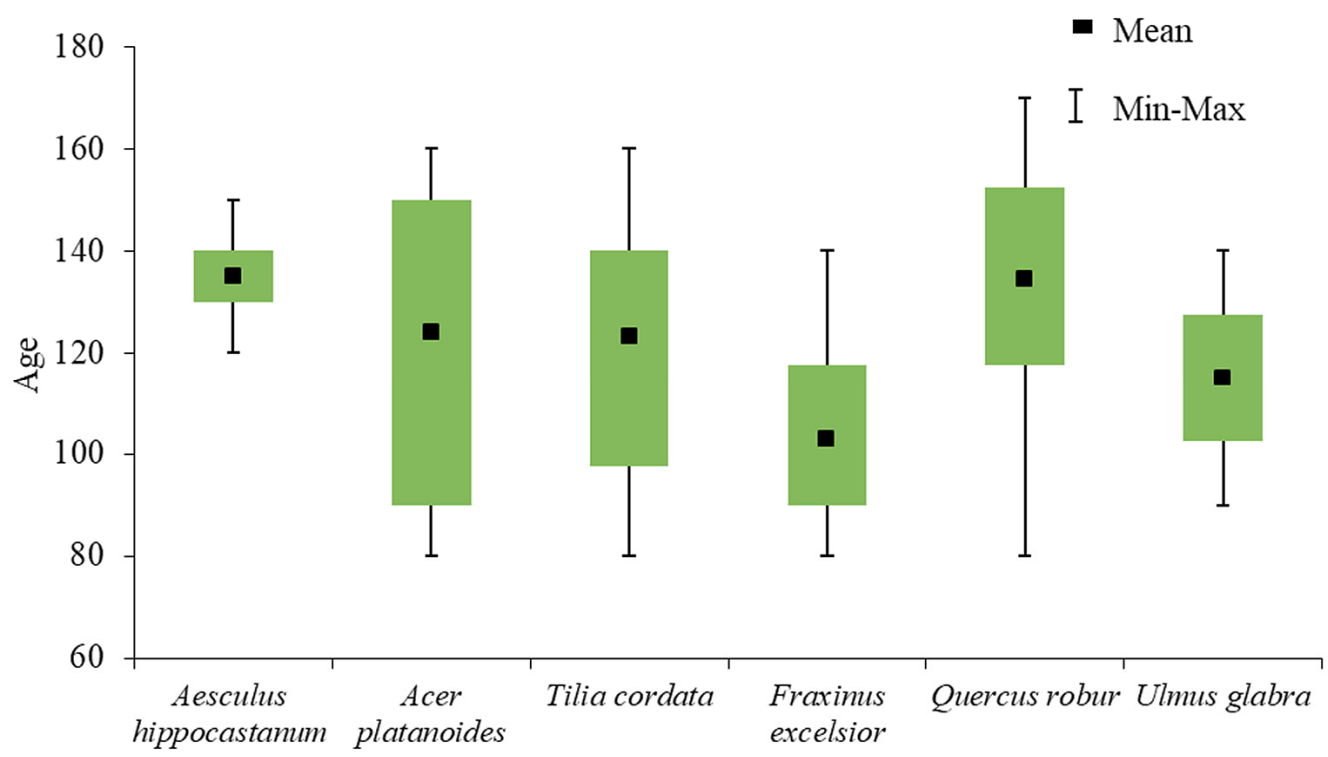

Fig. 6. Age variation of the oldest trees in former manors

Changes in the landscape components of the former manors Sustainable landscape is based on the optimal diversity and harmony of its elements and components. Stability of the objects is one of the most important criteria for maintaining authenticity. The relative sizes of the landscape components (Table 2) highlight the strength of their effect on the landscape structure.

Pavezgiai mansion comprised the largest number of buildings, all of which were wooden. In Pamusis II, the only remaining outbuilding occupied only $0.03 \%$ of the territory. The road network of the former manors has only slightly been modified. The main manor roads remained unchanged. Where modifications had been made, these were due to a decline in the condition of the road or to improve the overall aesthetic. Temporal changes in the natural landscape objects varied during the analyzed period. All rivers neighbouring the manors have become more abundant in water, and some riverbeds have significantly broadened. The landscape of Pamusis II has changed the most because the width of the Musa River has doubled. This resulted from adjustments to the dam (established in 2002), which turned the previous section of the river into a pond. The functioning of the same dam also changed the river water content in Impoliai manor. The artificial water bodies located in the grounds of the manors have only slightly changed.

An intentional reduction in greenery plots was observed in all manors. This reduces the aesthetic value of the landscape and poses a threat to natural systems. In Aukstadvaris, the area of grassland increased twice because 
Table 2. Change of former manors landscape components

\begin{tabular}{|c|c|c|c|c|c|c|c|c|c|c|c|c|}
\hline \multirow{3}{*}{$\begin{array}{l}\text { Former manor } \\
\text { objects }\end{array}$} & \multicolumn{12}{|c|}{ Percentage of landscape } \\
\hline & \multicolumn{2}{|c|}{ Pavezgiai } & \multicolumn{2}{|c|}{ Impoliai } & \multicolumn{2}{|c|}{ Pamusis II } & \multicolumn{2}{|c|}{ Dovydiskis } & \multicolumn{2}{|c|}{ Aukstadvaris } & \multicolumn{2}{|c|}{ Geruciai } \\
\hline & 1995 & 2009 & 1995 & 2009 & 1995 & 2009 & 1995 & 2009 & 1995 & 2009 & 1995 & 2009 \\
\hline Buildings & 3.0 & 3.0 & 0.4 & 0.4 & 0.0 & 0.0 & 0.6 & 0.6 & 0.8 & 0.8 & 1.3 & 1.3 \\
\hline Roads & 5.4 & 3.6 & 2.6 & 3.0 & 2.4 & 2.9 & 2.0 & 1.7 & 3.3 & 3.3 & 3.7 & 4.0 \\
\hline Ponds & 1.0 & 1.3 & 0.0 & 0.0 & 0.1 & 0.1 & 1.5 & 0.9 & 0.4 & 0.3 & 0.0 & 0.0 \\
\hline River & 0.4 & 0.9 & 13.7 & 15.1 & 14.2 & 30.8 & 0.0 & 0.0 & 0.0 & 0.0 & 1.4 & 1.6 \\
\hline Agricultural fields & 10.1 & 3.5 & 2.2 & 5.0 & 11.4 & 3.7 & 8.9 & 19.3 & 15.2 & 0.4 & 15.8 & 23.6 \\
\hline \multicolumn{13}{|l|}{ Green areas } \\
\hline grassland & 52.5 & 63.3 & 67.9 & 63.6 & 64.8 & 55.3 & 59.9 & 53.4 & 21.9 & 42.4 & 49.8 & 46.1 \\
\hline park trees & 5.9 & 3.4 & 3.2 & 2.6 & 4.2 & 3.0 & 13.9 & 11.9 & 15.5 & 12.6 & 7.6 & 5.4 \\
\hline other trees & 21.6 & 21.1 & 9.9 & 10.2 & 2.9 & 4.1 & 13.3 & 12.3 & 42.9 & 40.2 & 20.4 & 18.0 \\
\hline
\end{tabular}

the estate owners were engaged in the beekeeping business. The decline in the number of park trees could be attributed to Fraxinus excelsior dieback caused by the impact of the Chalara fraxinea pathogen. According to the owners, in 1999, hurricane Anatolijus devastated a considerable number of park trees. Several species of trees (Populus canescens, Quercus robur) have disappeared due to changes in the environmental conditions of the habitats (rise of water table level, more frequent extreme temperatures in winter, etc.) (Navasaitis and Navasaitis, 1979). The increase in the percentage coverage of other tree groups is a result of the spontaneous establishment of woody vegetation. Regressing green spaces lead to degradation of the landscape.

Over 14 years, some owners of the former estates (Pavezgiai, Pamusis II) reduced the arable land areas by three times, while arable land in Aukstadvaris is no longer used for its intended purpose and grasslands occupy the area. Other landowners (Dovydiskis, Geruciai) are engaged in intensive agricultural activities. In these former estates, the areas of agricultural fields have doubled. Expansion of agricultural fields is characteristic of the whole Pakruojis district. Under such circumstances, the role the former manors play in the preservation of sustainable landscape is particularly significant.

\section{Recreational resources}

The manors analyzed in the study serve important historical, material, and cultural purposes. However, they can also be employed for recreational purposes. One element of attraction is that famous people have lived in these manors; as such, they represent important cultural and ethnic landmarks. The rural landscape is also appealing to members of the urban population who seek opportunities to relax, vacation, or host celebrations in naturally beautiful areas (Mann et al., 2010; Thapa, 2010). A further element of appeal of these manors is that they hold a place in the heart of Lithuanians who have left the country due to economic emigration. These individuals commonly return to their ancestral homeland for holidays (Liubiniené, 2008).

In a monotonous rural landscape of cultivated fields in the Pakruojis district, the former manors could be potential recreational complexes; however, they are not currently suitable for full-rate recreation. Their appeal lies in the spatial distribution of objects, which combine a set of natural and anthropogenic elements (Pavezgiai, Dovydiskis, Geruciai).
The water bodies belonging to or adjacent to the manors also have recreational appeal (Fig. 4). In fact, kayak rental is already available at Impoliai manor. The riverbeds at Pavezgiai and Geruciai are attractive; however, the use of these rivers for water-based activities is complicated. Somewhat less attractive are the ponds remaining within the former manors. They are mainly used for household needs.

The manor parks undoubtedly add to the attractiveness of the landscape. The variety of park styles reflects the evolution of the European parks from Baroque parks (Geruciai, Pamusis II) to Romanticism (Dovydiskis) style. Visitors can marvel at the greenery composition of historic parks, explore age-old (Pamusis II, Geruciai) and fabled (Pavezgiai, Pamusis II) trees, and taste the fruit from historical orchards.

Sacral objects represent an additional element of attraction in the parks. Relics of burial crypts on the slopes of Aukstadvaris memorial hill provide unique spirituality to the area. The surviving authentic complex of wooden buildings that can be found at Pavezgiai manor increase the local recreational-educational value. Geruciai manor is distinguished by the construction technology of buildings that were used to build the first stone castles in Lithuania in the $14-15^{\text {th }}$ centuries and the relics of the defensive wall of that period.

The rural landscape in the Pakruojis district is minimal. This is due to the scarcity of forests and, as a consequence, low biodiversity. As such, the greenery surrounding the former manors increases the naturalness of the landscape and holds significant aesthetic value. Some parks (Pamusis II, Aukstadvaris) are overgrown with spontaneous plants that have overgrown any man-made features, and the empty spaces are occupied by secondary succession plants. Evidently, such parks have lost their original purpose; however, in the process of doing so, they have also acquired a new value - they have become a refuge for forest plants and animals.

\section{Discussion}

For a few centuries, a cohesive collection of separate manor estates formed a prominent feature of the Lithuanian state. The surviving manors are very valuable. They represent the durability of the Lithuanian state and are important historical, cultural, traditional, and economic 
symbols that reflect social, political, and national organization models and the associated changes. Over time, globalization, and political and economic changes have altered the rural landscape of Lithuania. A little more than 20 years ago, after the restoration of the independence from the Soviet Union, the country encountered many new challenges, and these were accompanied by the evolution of the landscape (Ribokas and Zlatkute, 2009). Due to the inexperience of the officials, the restoration of the land and buildings progressed in a chaotic manner. The lack of a uniform, consolidated plan for the development of historical buildings prevented the achievement of a balanced and harmonious co-existence of natural and anthropogenic components within the rural landscape that preserved important historical features while also responding to the contemporary needs of the community (KamičaitytèVirbašienė and Gražulevičiūtè-Vileniškè, 2010).

Undoubtedly, the vivid rural landscape can be preserved only by strengthening the traditional local communities, protecting intangible cultural heritage, and reviving traditional trades and crafts. The heritage of Lithuanian manors is a treasure for local communities; it greatly enriches the separate regions and districts of Lithuania and accentuates their character and identity. In many European countries, local communities highly value the cultural heritage situated in their territories and consider the right to maintain it to be a matter of honor and prestige (Garrod and Fyall, 2000). Recently, however, emigration caused by intensified globalization and economic changes has significantly increased in Lithuania (Thaut, 2009; Taran, 2011) and properties that have been recently returned to the former owners has often been left unattended, resulting in visual pollution. The declining population of the country has also had a negative impact on the recreation business (Oigenblick and Kirschenbaum, 2002) in the former manors. However, nostalgia for the historical past, increasing needs of people from larger cities to spend weekends in the ecological environment (Gartner, 2004), and aspirations of Lithuanians returning from abroad to spend their leisure time in countryside residences indicate that these former manors are suitable for the development of rural tourism (Liubiniene, 2008). It is also worth noting that, after the incorporation of Lithuania into the European Union, countryside recreation has become more popular (Kavaliauskas, 2008; Mann et al., 2010), promoting the development of rural tourism. Over the last decade, the number of rural tourist homesteads has doubled in Lithuania (Statistics Lithuania, 2018). It is also clear that areas with historical value and semantic significance (buildings, greenery spaces, stories, etc.) are appealing to visitors (Gartner, 2005; Kamičaityte-Virbašienè and Gražulevičiūtè-Vileniškè, 2010).

Usually, countryside recreation facilities are set up in wooded or rural areas that consist of natural components (forests, lakes, rivers, etc.). In the analyzed area, forest cover is about $19 \%$, while the average forest coverage of the country is about $33 \%$ (Januliene, 2007). Due to the fertile and productive soil, the number of large farmsteads is growing, and agricultural businesses have intensified (Statistics Lithuania, 2018); however, such developments have put biodiversity at risk (Kramer et al., 2009). This study revealed that the local systems of manors can stimulate the region provided the development of recreational activities and biodiversity conservation (Fig. 1) adheres to the principles of sustainable rural landscape development.

The former manors of the Pakruojis district that were analyzed in the current study integrate complexes of residential and farmyard buildings (Fig. 2) and greenery spaces (Fig. 3), and remain vivid objects within the rural landscape. Today, in a general sense, the former manors could be called homesteads. The current business environment can facilitate the development of innovative businesses that lead to the diversification of economic functions. Agro-tourism is particularly appealing because it can allow the homestead to become the object of polyfunctional activities. In the analyzed area, at least half of the former manors (Impoliai, Dovydskis, Geruciai) exhibited strong potential to become attractive recreational centers. The historical background of these former manors in combination with their setting in a natural and aesthetically pleasing environment create optimal conditions for recreation, tourism, or events.

\section{Conclusions}

Lithuania, a relatively small country, offers a unique and distinct landscape. Prominent political, historical, and economic events have actively shaped the evolution of the former manors that are dotted throughout this landscape.

In the studied territory, which is characterized by monoculture landscape, there is a need to preserve the manor parks because (1) they make a specific contribution to the overall form and aesthetic of the rural landscape, (2) play an important role in the conservation of biodiversity, and (3) represent significant cultural and historical landmarks. In such areas, further neglect of the greenery heritage will inevitably lead to the degradation of the landscape. The current study revealed that former manors that are not bound with settlements could be adapted for the development of agritourism. This would represent a sustainable solution by which the rural landscape can be preserved while also meeting the contemporary needs of Lithuanians. To maintain the sustainable development of these locations in this regard, there is a need to restore and preserve them. Further studies should determine the exact requirements for the reconstruction and renovation of the surviving buildings within the planned concept of area development.

\section{References}

Bebbington AJ, Batterbury SPJ (2001). Transnational livelihoods and landscapes. Political Ecologies of Globalization. Cultural Geographies 8:369-380.

Bukantis A, Gedžiunas P, Giedraitiene J, Ignatavičius G, Jonynas J, Kavaliauskas P, ... Valiukevičius G (2008). Lietuvos gamtine aplinka, büklè, procesai ir raida [Lithuanian natural environment, condition, processes and development]. Vilnius

Cheshire L, Woods M (2013). Globally engaged farmers as transnational actors: Navigating the landscape of agri-food globalization. Geoforum 44:232-242 
678

Elsner B (2010). Does emigration benefit the stayers? The EU Enlargement as a natural experiment. Evidence from Lithuania. The Institute for International Integration Studies. Discussion Paper 326:1-39.

Garrod B, Fyall A (2000). Managing heritage tourism. Annals of Tourism Research 27(3):682-708.

Gartner CW (2004). Rural tourism development in the USA. International Journal of Tourism Research 6:151-164.

Gartner CW (2005). A perspective on rural tourism development. The Journal of Regional Analysis and Policy 35(1):33-42.

Gražulis A (2008). Lietuvos dvarų paveldo apsaugos, atgaivinimo ir integravimo i šiuolaikiness visuomenès gyvenimą problemos [The problems of Lithuanian heritage mansions protection, resurrection and integration into modern society]. Retrieved 2018 January 15 from http //www3.lrs.tt/pls/inter/w5_show?p_r=871\&p_d=81754\&p_k=1.

Isokas G (1995). Lietuvos gamtos paminklai [Lithuanian natural monuments].Vilnius.

Janulienė L (2007). Pakruojo rajono savivaldybes teritorijos bendrasis planas [Territory master plan of Pakruojis district municipality].Vilnius.

Janulyte V, Puriene A, Petrauskiene J, Peciuliene V, Benzian H (2011). International migration of Lithuanian oral health professionals: a survey of graduates. International Dental Journal 61(4):224230.

Januškevičius L, Baronienė V, Liagienè V (2006). Sumedëjusių augalų introdukcija ir aklimatizacija bei jų rezultatai ir perspektyvos Lietuvoje [Results and perspectives of woody plant introduction and acclimatization in Lithuania]. Kaunas.

Kačinskaite I (2009). Lietuvos dvarų sodų parkų tyrimai [Research of Lithuanian manor gardens and parks]. Acta Academiae Artium Vilnensis 55:133-147.

Kamičaitytè-Virbašiene J, Gražulevičiūte-Vileniške I (2010). Istoriniai Lietuvos dvarų sodybų želdynai: kraštovaizdžio architektūros kūriniai ir paveldosaugos objektai [Historic gardens of Lithuanian manor residencies: works of landscape architecture and objects of historic preservation]. Kürybos Erdvès 12:38-50.

Kavaliauskas P (2008). A concept of sustainable development for regional land use planning: Lithuanian experience. Technological and economic development of economy. Baltic Journal on Sustainability 14(1):51-63.

Kramer DB, Urquhart G, Schmitt K (2009). Globalization and the connection of remote communities: A review of household effects and their biodiversity implications. Ecological Economics 68:2897-2909.

Lazdinis M, Roberge JM, Kurlavičius P, Mozgeris G, Angelstam P (2005). Afforestation planning and biodiversity conservation: Predicting effects on habitat functionality in Lithuania. Environmental Planning and Management 48(3):331-348.

Liubiniene $N$ (2008). Lithuanians in Northern Ireland: New home, new homeland? Irish Journal of Anthropology 11(1):9-13.
Majdecki L (1980-1986). Tabela wiekowa drzew [Age table of trees]. Rkps, Oddział Architektury KrajobrazuSGGW, Warszawa.

Mann C, Pouta E, Gentin S, Jensen FS (2010). Outdoor recreation in forest policy and legislation: A European comparison. Urban Forestry and Urban Greening 9:303-312.

Mincyte D (2011). Subsistence and sustainability in post-industrial Europe: The politics of small-scale farming in Europeanising Lithuania. Sociologia Ruralis 51(2):101-118.

Ministry of Environment State Forest Survey Service (2012). Lithuanian statistical yearbook of forestry. Kaunas.

Navasaitis A, Navasaitis M (1979).Lietuvos medžiai [Lithuanian trees]. Vilnius: Mokslas.

Oigenblicka L, Kirschenbauma A (2002). Tourism and immigration: Comparing alternative approaches. Annals of Tourism Research 29(4):1086-1100.

Pašakarnis G, Maliene V (2010). Towards sustainable rural development in Central and Eastern Europe: Applying land consolidation. Land Use Policy 27:545-549.

Paulikas VK, Lazdinis I (2006). Sustainable agriculture and forestry in Lithuania: constraints and opportunities. Small-Scale Forestry and Rural Development: The Intersection of Ecosystems, Economics and Society 376-385.

Ribokas G, Zlatkutė A (2009). Žemėnaudos kaita Anykščiu rajono savivaldybëje (Viešintų seniūnijos pavyzdžiu) [Land Use Dynamics in the Anykščiai District Municipality (the Case of Viešintos Local Administrative Unit]. Annales Geographicae 42(1-2):45-54.

Statistics Lithuania (2018). Data base of indicators. Retrieved 2018 January 13 from http//dbl.stat.govlt/statbank/defaultasp?w=1280.

Šliburyte L, Masteikienè R (2010). Impacts of globalization on Lithuanian economic growth. Economics and Management 15:288-294.

Taran PA (2011). Globalization, migration and labour: imperatives for a rights based policy.Journal of Globalization Studies 2(1):58-77.

Thapa B (2010). The mediation effect of outdoor recreation participation on environmental attitude-behavior correspondence. The Journal of Environmental Education 41(3):133-150.

Thaut L (2009). EU integration \& emigration consequences: The case of Lithuania. International Migration 47(1):191-233.

Vaiškūnaitė R, Mierauskas P, Špakauskas V (2012). Biodiversity impact assessment in road development in Lithuania. Transport 27(2):187195.

Vaitkus G, Vaitkuvienė D (2005). Land cover changes in the Lithuanian coastal zone during 1975-2000. Acta Zoologica Lituanica 15(2):183187.

Lietuvos dvarų duomenų bazė [Lithuanian mansions database] (2017). Retrieved 2017 October 24 from http//www.heritagelt. 